\title{
Review
}

\section{Pleural, peritoneal and pericardial effusions - a biochemical approach}

\author{
Lara Milevoj Kopcinovic*1, Jelena Culej ${ }^{2}$ \\ ${ }^{1}$ Medical School University Hospital Sestre Milosrdnice, University Department of Chemistry, Zagreb, Croatia \\ ${ }^{2}$ Medical School University Hospital Sestre Milosrdnice, Department of Transfusiology and Hemostasis, Zagreb, Croatia \\ ${ }^{*}$ Corresponding author: laramilevoj@gmail.com
}

\begin{abstract}
The pathological accumulation of serous fluids in the pleural, peritoneal and pericardial space occurs in a variety of conditions. Since patient management depends on right and timely diagnosis, biochemical analysis of extravascular body fluids is considered a valuable tool in the patient management process.

The biochemical evaluation of serous fluids includes the determination of gross appearance, differentiation of transudative from exudative effusions and additional specific biochemical testing to assess the effusion etiology. This article summarized data from the most relevant literature concerning practice with special emphasis on usefulness of biochemical tests used for the investigation of pleural, peritoneal and pericardial effusions. Additionally, preanalytical issues concerning serous fluid analysis were addressed and recommendations concerning acceptable analytical practice in serous fluid analysis were presented.
\end{abstract}

Key words: pleural effusion; peritoneal effusion; pericardial effusion

\section{Introduction}

Blood, urine and cerebrospinal fluid are standard samples analyzed in the clinical laboratory. However, occasionally the evaluation of serous extravascular fluids (i.e. pleural, peritoneal and pericardial) is requested. Biochemical analysis of such samples can provide the clinician valuable information about the fluid's etiology and refer him to final diagnosis and treatment options.

\section{Pleural effusions}

Pleural effusions result from excessive fluid formation and its accumulation in the pleural space. The most common conditions causing pleural effusions are heart failure, malignancy, pneumonia, tuberculosis and pulmonary embolism. In patients presenting with pleural effusions, efforts should be made to find out the cause so that appropriate treatment can be instituted $(1,2)$.
Patient history and physical examination are crucial for the clinical evaluation of pleural effusions. They are followed by confirmation of pleural effusion presence using radiological or/and ultrasound studies or computed tomography (CT) chest scans. Thoracentesis, the removal of pleural fluid using a needle or syringe, is performed either for diagnostic or therapeutic purposes. It should be coupled with blood sampling (within 30 minutes from obtaining the pleural fluid sample) needed for further effusion evaluation, i.e. the differentiation of transudative from exudative effusions (3).

In most cases of pleural effusions, especially if no underlying diagnosis is apparent, biochemical analyses provide important diagnostic information. Various tests can be performed for pleural fluid (PF) analysis, either as sole or additional diagnostic tools to further determine the effusion's etiology $(4,5)$. 


\section{Appearance of pleural fluid}

Although fluid appearance is a nonspecific tool in the evaluation of PF it can provide useful information about the etiology of pleural effusion.

Most transudates and many exudates are clear, straw-colored, odorless and non-viscous fluids (6). A homogeneous bloody appearance, with PF hematocrit of $1-20 \%$ of peripheral, narrows the differential diagnosis to malignancy, embolism or trauma. A PF hematocrit, exceeding half of the peripheral hematocrit, is indicative of hemothorax. Turbidity of PF can be caused by either the presence of cells and debris or by a high lipid concentration in PF. A clear supernatant, after centrifugation of turbid PFs, indicates that turbidity is caused by cells and debris which might indicate the presence of empyema. Otherwise, if turbidity persists after centrifugation, it is probably due to high lipid concentration, suggesting the presence of chylothorax or pseudochylothorax. Nevertheless, PF triglyceride analysis is a more definitive test and concentrations $>1.2 \mathrm{mmol} / \mathrm{L}$ indicate that the $\mathrm{PF}$ is chyle. An anchovy-brown fluid may indicate amebic liver abscess while black fluid suggests Aspergillus infection $(4,5,7)$.

\section{Differentiation of exudates from transudates}

The initial step in the biochemical evaluation of pleural effusions is to determine whether they are transudative or exudative (Figure 1). Transudative pleural effusions are caused by systemic non-inflammatory conditions such as heart failure and cirrhosis. They respond to treatment of underlying disease. Exudative effusions are caused by an inflammatory or malignant process affecting the pleura, causing increased capillary permeability and fluid accumulation. Common causes of exudates include pneumonia, cancer, tuberculosis and pulmonary embolism. An extensive diagnostic investigation is required to determine a definite diagnosis $(1,5)$.

In clinical practice, Light's criteria have been widely accepted to differentiate transudates from exudates for the past 40 years (Table 1) $(6,8)$. In their original study Light et al. reported a sensitivity of
TABLE 1. Light's criteria for the differentiation of pleural effusions.

\begin{tabular}{cccc}
\hline Pleural fluid & $\begin{array}{c}\text { PF/serum } \\
\text { protein ratio }\end{array}$ & $\begin{array}{c}\text { PF/serum } \\
\text { LD ratio }\end{array}$ & PF LD (U/L) \\
\hline Transudative & $<0.5$ & $<0.6$ & $<2 / 3 \mathrm{URL}$ \\
Exudative* $^{*}$ & $\geq 0.5$ & $\geq 0.6$ & $\geq 2 / 3 \mathrm{URL}$ \\
\hline
\end{tabular}

*Effusions are identified as exudative if one or more conditions are met.

LD - lactate dehydrogenase; PF - pleural fluid; URL - upper reference limit of serum LD.

$99 \%$ and specificity of $98 \%$ in identifying exudates. In subsequent studies, the original sensitivity of Light's criteria was reproduced, but with lower specificities (ranging from $65 \%$ to $86 \%$ ) and consequently higher misclassification rates of transudates into exudates $(6,9,10)$. Despite this limitation, Light's criteria were reported to be superior to clinical judgment alone in the differentiation of transudates and exudates (11).

Various studies have focused on making Light's criteria more cost-effective without affecting its diagnostic accuracy. Better diagnostic performances in comparison to Light's criteria were obtained by quantifying exclusively PF protein and PF lactate dehydrogenase (LD) (12). An early investigation of PF cholesterol suggested that concentrations $>1.6$ $\mathrm{mmol} / \mathrm{L}$ were a cost-effective single test that might be used as an alternative to Light's criteria in the differentiation of exudative from transudative effusions (13). However, these results were not corroborated by subsequent studies $(14,15)$. Additional biochemical parameters (and their combinations) have been investigated to differentiate the two effusion types. Porcel et al. proposed measurement of cholesterol and LD in PF as an alternative to Light's criteria for the identification of exudates without requiring blood sampling, while Costa et al. found that PF cholesterol $>1.2 \mathrm{mmol} / \mathrm{L}$ and/or PF LD > $200 \mathrm{U} / \mathrm{L}$ revealed similar diagnostic accuracy to Light's criteria for the differentiation of PFs $(16,17)$. Recently, concentration of ischemiamodified albumin (IMA) has been found to be increased in transudative pleural effusions compared to tuberculous effusions, and measurement of 


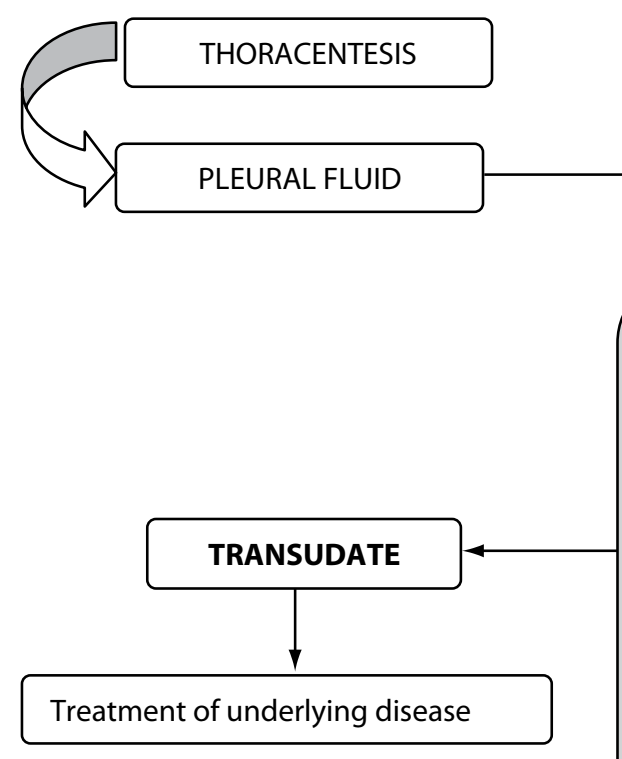

STEP1. APPEARANCE

- gross examination before centrifugation

\section{STEP 2. TRANSUDATE/EXUDATE DIFFERENTIATION}

Light's criteria for pleural fluid exudate:

a) Pleural fluid/serum protein ratio $\geq 0.5$ and/or

b) Pleural fluid/serum LD $\geq 0.6$ and/or

c) Pleural fluid $L D \geq 2 / 3$ URL.

Useful additional tests for exudate identification:

a) SEAG (in patients treated with diuretics) $<12 / \mathrm{L}$

b) Pleural fluid cholesterol $>1.2 \mathrm{mmol} / \mathrm{L}$

c) Pleural fluid NT- proBNP (in patients with CHF) $<$ $1500 \mathrm{ng} / \mathrm{L}$

d) Pleural fluid IMA $<4711 \mathrm{ng} / \mathrm{mL}$.

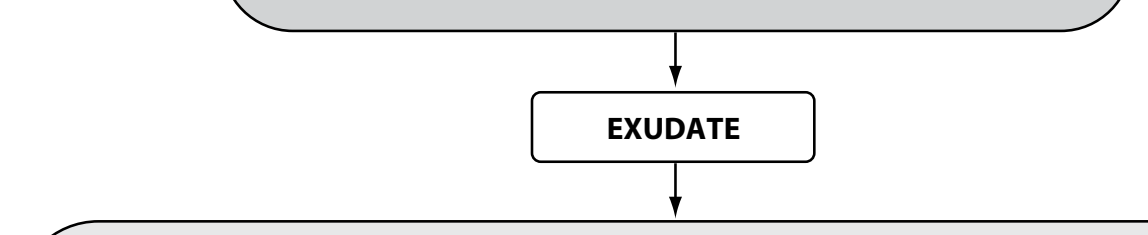

STEP 3. SPECIFIC PLEURAL FLUID TESTS FOR EXUDATE EVALUATION:

a) Total and differential cell count (total leukocytes $>500 \times 10^{6} / \mathrm{L}$, neutrophil predominance in acute inflammatory processes)

b) $\mathrm{pH}(<7.300$ predicts shorter survival in malignant effusions)

c) Glucose (<3.4 mmol/L in parapneumonic effusions, malignant disease or tuberculosis)

d) Triglycerides ( $>1.2 \mathrm{mmol} / \mathrm{L}$ in chylothorax, $<0.6 \mathrm{mmol} / \mathrm{L}$ in pseudochylothorax)

e) Cholesterol ( $<5.2 \mathrm{mmol} / \mathrm{L}$ in chylothorax, $>5.1 \mathrm{mmol} / \mathrm{L}$ in pseudochylothorax)

f) $\mathrm{ADA}$ ( $>40 \mathrm{U} / \mathrm{L}$ in tuberculous peritonitis)

g) IFN- $\gamma$ (lack of definite cutoff point)

h) Amylase (pleural fluid/serum ratio $>1$ in pancreatic pseudocyst, malignant disease, liver cirrhosis, esophageal rupture)

i) Creatinine (pleural fluid/serum ratio $>1$ in urinothorax)

j) $\quad$ CRP (> $53 \mathrm{mg} / \mathrm{L}$ in parapneumonic versus malignant effusions).

Figure 1. Biochemical analysis of pleural effusions.

LD - lactate dehydrogenase; URL - upper reference limit of serum LD; SEAG - serum effusion albumin gradient; NT-proBNP- N-terminal brain natriuretic peptide precursor; CHF - congestive heart failure; IMA- ischemia-modified albumin; ADA - adenosine deaminase; IFN- $\gamma$ - Interferon- $\gamma$; CRP - C-reactive protein.

pleural IMA showed good diagnostic performances (although not superior to Light's criteria) in transudate/exudate differentiation (18). Additional biochemical parameters have also been investigated for this purpose, including alkaline phosphatase (ALP), creatine kinase and uric acid. They showed poorer diagnostic performances compared to Light's criteria (19).

It has been estimated that up to $25 \%$ of cardiacrelated pleural effusions are misclassified as exudative in patients with congestive heart failure (CHF) due to the use of diuretics (20). Diuretic ther- 
apy in patients with CHF was reported to cause fluid shifting from the pleural space, thus elevating concentrations of various PF components, including PF protein and PF LD. Consequently, transudative pleural effusions associated with CHF could fulfill exudative diagnostic criteria $(4,21)$. After the introduction of the serum effusion albumin gradient (SEAG), calculated as the difference between serum and PF albumin concentration, the misclassification of transudative effusions in patients treated with diuretics was significantly reduced. If SEAG is $>12 \mathrm{~g} / \mathrm{L}$, the effusion is classified as transudate. However, because of its low sensitivity, the albumin gradient should not be used individually to distinguish transudates from exudates. Thus, if the clinical appearance suggests transudative effusion, particularly in cases of CHF or cirrhosis, but the PF is exudative according to Light's criteria, SEAG calculation is recommended $(9,10,14)$. In recent years it has been shown that $\mathrm{N}$ terminal brain natriuretic peptide precursor (NTproBNP) concentrations are increased in PF and serum of patients with CHF and pleural effusion. Pleural fluid NT-proBNP values $\geq 1500 \mathrm{ng} / \mathrm{L}$ can differentiate pleural effusions caused by heart failure from pleural effusions caused by other etiology with sensitivity and specificity of $91 \%$ and $93 \%$, respectively (20). Additional studies demonstrated the superiority of pleural NT-proBNP determination over Light's criteria for the identification of cardiac-related pleural effusions. However, caution is needed when interpreting NT-proBNP results, as concentration of NT-proBNP is physiologically raised in the elderly and in patients with renal failure (22-25).

When comparing the discriminative properties of different biochemical markers for the identification of exudative effusions, the meta-analysis published by Heffner et al. should be considered. The authors confirmed that combinations of two or three tests performed only in PF specimens (i.e. the combined use of PF LD and PF cholesterol or PF LD, PF cholesterol and PF protein), showed similar diagnostic performances to modified Light's criteria, reducing the costs of diagnosis and avoiding the need for blood sampling. Heffner et al. also demonstrated that excluding PF LD from Light's criteria did not alter the diagnostic accuracy of the remaining combination (i.e. PF/serum LD ratio and $\mathrm{PF} /$ serum protein ratio). However, no superior combination of tests was proposed (26).

All of the aforementioned tests dichotomize effusions into transudative or exudative by comparing the results to a cut-off point. The diagnostic performances of each of these tests are described by means of sensitivity and specificity. Applicability of sensitivity and specificity values on individual patients in clinical practice is limited, because these measures do not describe the probability of disease if a positive test result is obtained. In addition, the combination of multiple tests, using a single cut-off point for each test, increases sensitivity but decreases specificity, implying the need for additional (and often unnecessary) tests to clarify diagnosis. A Bayesian approach addresses the limitations of binary testing by quantifying diagnostic confidence. This concept suggests that a test alone does not differentiate exudate from transudate, rather that the test only influences the pre-test probability of being a transudate or exudate. Multilevel likelihood ratios, for tests routinely performed to discriminate between transudates and exudates, were reported and can be used to estimate the post-test probability of exudative effusions. However, the familiarity and simplicity of Light's criteria should be balanced against the introduction of new and cumbersome methods for differentiating transudates from exudates (27-29).

\section{Evaluation of exudative effusions}

Once a pleural effusion is characterized as an exudate, the next challenge is to identify its etiology. Depending on clinical presentation, exudative effusions need additional testing (Figure 1). This includes total and differential cell counts, smears and cultures to identify infection, additional biochemical testing, cytological analysis and testing for markers of tuberculous pleuritis $(5,8)$.

In general, most exudates have $>500 \times 10^{6} / \mathrm{L}$ leukocytes (30). Although differential leukocyte count in PF is of limited diagnostic value, it reflects the stage of the inflammatory response and narrows the diagnostic possibilities. Neutrophil predomi- 
nance indicates an acute inflammatory process affecting the pleura that may occur in the case of parapneumonia, pulmonary embolism, viral infections, gastrointestinal diseases and tuberculous pleuritis. Predominance of mononuclear cells indicates a subacute or chronic process. Pleural lymphocytosis is indicative of malignant or tuberculous pleuritis, whereas pleural eosinophilia (at least $10 \%$ of eosinophils) is caused mainly by blood or air in the pleural space (i.e. malignancy or pneumothorax) $(4,6,8)$.

The exudative $\mathrm{pH}$ ranges from 7.440 to 7.300 (30). Several conditions, such as systemic acidosis, local anesthetics entered in the pleural space or Proteus infections, can cause local alkalosis and modify the $\mathrm{pH}$ values of the PF. Therefore, $\mathrm{PF} \mathrm{pH}$ results should always be interpreted in accordance to the clinical context. A pH value below 7.200 (and/or PF LD higher $>3$ times the upper serum reference limit) in patients with parapneumonic effusion indicates the need for fluid drainage (31). A pH value below 7.300 in patients with malignant effusions predicts shorter survival and a poorer response to chemical pleurodesis. When PF pH is not available, low PF glucose concentration $(<3.4 \mathrm{mmol} / \mathrm{L})$ indicates the presence of complicated parapneumonic effusion, malignant disease or tuberculosis $(1,6,8)$.

Determination of triglyceride and cholesterol concentrations is useful in the diagnosis of chylothorax and pseudochylothorax. A chylothorax is defined as the accumulation of lymph or chyle in the pleural space after leak from the thoracic duct, most often due to trauma, surgery or malignancy. A pseudochylothorax results from the accumulation of cholesterol and/or lecithin and globulin rich fluid in long standing PFs. PF triglyceride concentrations $>1.2 \mathrm{mmol} / \mathrm{L}$ are confirmatory of chylothorax. Usually, PF cholesterol is determined simultaneously to exclude the presence of pseudochylothorax: concentrations $<5.2 \mathrm{mmol} / \mathrm{L}$ are associated with chylothorax. PF triglycerides $<0.6$ $\mathrm{mmol} / \mathrm{L}$ and $\mathrm{PF}$ cholesterol $>5.1 \mathrm{mmol} / \mathrm{L}$ are found in pseudochylothorax. Nevertheless, the gold standard for diagnosing chylothorax is the detection of chylomicrons in PF by means of lipoprotein analysis $(22,32)$.
In clinical practice, the diagnosis of tuberculous pleurisy is usually established using the combination of PF microscopic examination and PF cultures. The sensitivity of these conventional methods for diagnosing tuberculous pleural effusions was reported to be less than $50 \%$. Thus, several biochemical markers have been proposed to facilitate the diagnosis of tuberculous pleurisy. Interferon- $\gamma$ (IFN- $\gamma$ ) and adenosine deaminase (ADA) are both released during the immune response to mycobacterial antigens in the pleura and have been extensively studied (33). IFN- $\gamma$ has proven to be a sensitive and specific marker in diagnosing tuberculous pleural effusions. Investigators reported sensitivity and specificity of $89 \%$ and $97 \%$, respectively $(34,35)$. ADA is an enzyme involved in purine catabolism and is thought to reflect the activity of immune cells $(6,34)$. It is released by activated lymphocytes, macrophages and neutrophils, and is considered a nonspecific marker of inflammation (36). Elevated ADA activity in PF is a sensitive and specific marker for the diagnosis of tuberculous pleuritis, particularly in high prevalence areas, with reported sensitivity of $92 \%$ and specificity of $90 \%$ at a generally accepted cutoff point of $40 \mathrm{U} / \mathrm{L}(37,38)$. Despite the high diagnostic performances of both biomarkers, ADA is commonly used in clinical practice, due to lower costs and the lack of a definite cutoff point for IFN- $\gamma$. However, since none of these PF biomarkers is specific for tuberculous pleuritis, results should be interpreted in accordance with clinical and microbiologic findings $(22,33,37,38)$.

Additional biomarkers have been studied in the setting of tuberculous pleural effusions, including PF neopterin, leptin, lysozyme, interleukine (IL)-6, IL-1 $\beta$, IL-8 and others. Variable diagnostic performances obtained and high costs preclude their introduction into routine clinical practice. To overcome the limitations of individual tests, various scoring systems, using clinical and laboratory data, have been proposed for the differentiation of tuberculous and malignant pleural effusions. They seem to perform better than any single test (36).

Cytological examination of suspected malignant PFs, although fast and efficient in cancer diagnosis, can result in false negative results in up to $40 \%$ 
of patients. The diagnostic performances of cytology are related to tumor type, tumor burden in the pleural space and the cytologist's competence (1). Although single PF tumor markers such as carcinoembryonic antigen (CEA), CA 125, CA 15-3 and CYFRA 21-1 have been investigated as noninvasive procedures for diagnosing pleural malignancy, the obtained results are discordant and the usefulness limited due to low sensitivity. In an effort to improve sensitivity, combinations of tumor markers have been studied, such as CEA, CA 125 and CYFRA 21-1 or CEA, CA 15-3, CYFRA 21-1 and CA 125. It was demonstrated that such combinations could be considered valuable complementary tools in the diagnosis of malignant $\mathrm{PF}$, improving the diagnostic value of PF cytology. However, the routine determination of tumor markers in the diagnosis of malignant pleural effusions is not recommended because it is not cost-effective. In cases of suspicious malignant pleural effusion and negative cytological findings, or in the absence of an obvious primary source, the determination of tumor markers may be helpful as an alternative diagnostic tool indicating the need for pleural biopsy $(6,10,39,40)$.

High activity of amylase (AMY) in PF is defined as values exceeding the serum reference range or as PF to serum AMY ratio $>1$ (22). Elevated PF AMY is found in patients with pancreatic disease and pancreatic pseudocysts, malignant disease, liver cirrhosis and esophageal rupture. The routine measurement of AMY in PFs is not useful in the absence of these indications $(41,42)$. Increased PF creatinine concentrations (PF/serum creatinine ratio $>1$ ) are useful in the diagnosis of urinothorax. The PF has typically transudative characteristics with marked urine odor, low glucose concentrations and low $\mathrm{pH}(10,43)$. Although rare, cerebrospinal fluid (CSF) can accumulate in the pleural space and result in an effusion. The presence of CSF is suggested by very low protein concentration in the PF and confirmed by $\beta_{2}$-transferrin detection, which is normally present only in CSF (43). PF immunological tests, such as determination of antinuclear antibody (ANA) titer or rheumatoid factor (RF) levels are accessible but add little diagnostic information to serum immunological analyses $(4,5,22)$.
Features of PF analysis that discriminate infection from inflammation in the complicated versus noncomplicated setting include pleural C-reactive protein, IL-8, IL-6, tumor necrosis factor (TNF)-a and procalcitonin. Pleural CRP is higher in non-malignant versus malignant exudates, with high sensitivity and specificity for parapneumonic effusion. Further studies showed that a PF CRP cut-off value of $53 \mathrm{mg} / \mathrm{L}$ has $100 \%$ sensitivity in identifying parapneumonic versus tuberculous or malignant effusions (44). CRP measured together with IL-8 may differentiate complicated from uncomplicated parapneumonic effusions with high sensitivity and specificity (4).

\section{Peritoneal effusions}

Peritoneal effusions (or ascites) represent the pathological collection of fluid in the peritoneal cavity. Common causes include liver cirrhosis, malignancy, congestive heart failure, tuberculosis, nephrotic syndrome, pancreatic disease and dialysis (6). History and physical examination provide clues to the possible etiology of ascites formation. Abdominal radiological, ultrasound and $C T$ studies can help detect small volumes of peritoneal fluid as well as assess the possible etiology of ascites. However, diagnostic paracentesis, i.e. the removal of peritoneal fluid, is recommended in patients presenting with new-onset ascites, requiring hospitalization due to the presence of ascites or in cases of unexplained deterioration of clinical findings $(45,46)$. Abdominal paracentesis with appropriate ascitic fluid biochemical analysis is considered the most rapid and cost-effective method for diagnosing the cause of ascites (47).

\section{Appearance of peritoneal fluid}

Ascites is a clear, straw-colored fluid and usually reflects the presence of cirrhosis. Bloody ascitic fluid, if not caused by traumatic tap, indicates malignancy, pancreatitis or abdominal trauma. When the bloody appearance of ascitic fluid is caused by traumatic tap, the fluid tends to clear up and/or tends to clot when left to stand after paracentesis. Purulent ascites is usually caused by abdominal infection and accompanied by an increased number 
of polymorphonuclear (PMN) leukocytes. In conditions of complicated hemorrhagic pancreatitis, the ascitic fluid color ranges from tea-colored to black. Bile stained ascites is usually found in gallbladder or intestine perforation, cholecystitis or acute pancreatitis. Milky or turbid ascites appearance is characteristic for lymph effusions due to high triglyceride content. The turbidity of chylous ascites can be cleared by addition of a few drops of ether. Pseudochylous ascites also appears turbid but is not cleared by ether. Black colored ascites can be found in malignant melanoma $(6,48)$.

\section{Differentiation of exudates from transudates}

As with pleural effusion analysis, the biochemical evaluation of ascites begins with differentiation of transudative from exudative effusions (Figure 2). This concept is based on the assumption that ascites, formed by exudation from the peritoneal surface affected by inflammatory process or tumor, has high protein concentrations. Conversely, fluid formed by transudation as a result of systemic conditions such as cirrhosis, heart failure or nephrotic syndrome, has low protein concentrations (49). Ascites protein cut-off in the range of 25 to 30 $\mathrm{g} / \mathrm{L}$ has been traditionally used for separating ascites into transudative or exudative. However, this approach yielded poor sensitivity and frequent misclassifications. Furthermore, it does not address ascites of mixed origin, i.e. caused by an underlying disorder besides portal hypertension. Additionally, it was observed that healthy women frequently have a peritoneal fluid protein concentration above $40 \mathrm{~g} / \mathrm{L}$, well into the exudative range. A modification of the original Light's criteria for the identification of exudative ascites was suggested (Table 2) $(6,45)$. Other biochemical parameters, such as ascitic/serum bilirubin ratio, ascitic cholesterol and ascitic/serum cholesterol ratio, have been investigated for the differentiation of transudative from exudative ascites, but have not been implemented into routine practice due to lack of reproducibility between studies. Furthermore, a practical model, including determinations of total protein, LD, TNF-a, complement C4 and haptoglobin in ascitic fluid, was investigated, that correctly classified $70 \%$ of unknown cases of malignant ascites
TABLE 2. Modification of Light's criteria for the differentiation of ascites.

\begin{tabular}{cccc}
\hline Ascites & $\begin{array}{c}\text { Ascites/serum } \\
\text { protein ratio }\end{array}$ & $\begin{array}{c}\text { Ascites/serum } \\
\text { LD ratio }\end{array}$ & $\begin{array}{c}\text { Ascites LD } \\
\text { (U/L) }\end{array}$ \\
\hline Transudative & $<0.5$ & $<0.6$ & $<400$ \\
Exudative* $^{*}$ & $\geq 0.5$ & $\geq 0.6$ & $\geq 400$ \\
\hline
\end{tabular}

*Effusions are identified as exudative if at least two conditions are met.

LD - lactate dehydrogenase.

$(6,50,51)$. Although promising, these results need to be further developed in the clinical setting before implementation into routine clinical practice (51). Serum ascites albumin gradient (SAAG) has been proposed as a physiologically based alternative to the traditional classification of ascites into transudates/exudates (52). SAAG is calculated as the difference between serum and ascites albumin concentration and was demonstrated to correlate directly with measured portal pressure (6). Consequently, SAAG $\geq 11 \mathrm{~g} / \mathrm{L}$ suggests the presence of portal hypertension, while SAAG values $<11 \mathrm{~g} / \mathrm{L}$ are found in patients with normal portal pressure. In a large prospective study, SAAG and ascitic total protein concentration yielded a diagnostic accuracy of $97 \%$ and $56 \%$, respectively, in the differentiation of ascites caused by portal hypertension (49). This marked difference in accuracies was explained by factors influencing these parameters: while SAAG directly correlates only with portal pressure, ascitic total protein concentrations are indirectly related to portal pressure but directly related to serum protein concentrations. In patients with cirrhosis, these influencing factors contribute variably, explaining the highly variable ascitic total protein concentration. Given the superiority of the SAAG concept, the replacement of the traditional transudate/exudate concept was proposed. Ascitic fluid should be classified as high-albumin gradient or low-albumin gradient depending on the SAAG value $(49,53,54)$. Both SAAG and ascitic fluid protein concentration are recommended for the initial evaluation of ascitic fluid in cirrhosis, proposed by the American Association for the Study of Liver Disease (AASLD) and British Society of Gastroenterology $(47,55)$. 


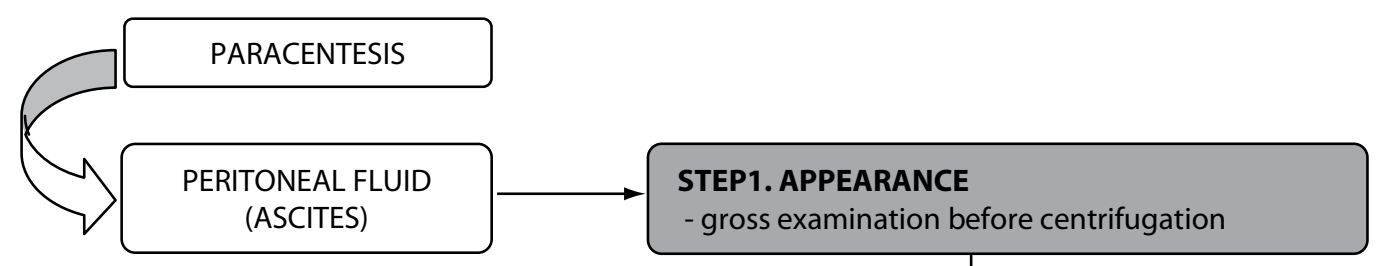

\section{STEP 2a. TRANSUDATE/EXUDATE DIFFERENTIATION}

Modified Light's criteria for peritoneal fluid exudate:

a) Peritoneal fluid/serum protein ratio $\geq 0.5$

b) Peritoneal fluid/serum LD $\geq 0.6$

c) Peritoneal fluid LD $\geq 400 \mathrm{U} / \mathrm{L}$. *

* Effusions are identified as exudates if at least two criteria are met.

\section{STEP 2b. TRANSUDATE/EXUDATE DIFFERENTIATION}

SAAG:

a) $\geq 11 \mathrm{~g} / \mathrm{L}$ - high albumin gradient peritoneal effusion; transudate

b) $<11 \mathrm{~g} / \mathrm{L}$ - low albumin gradient peritoneal effusion; exudate

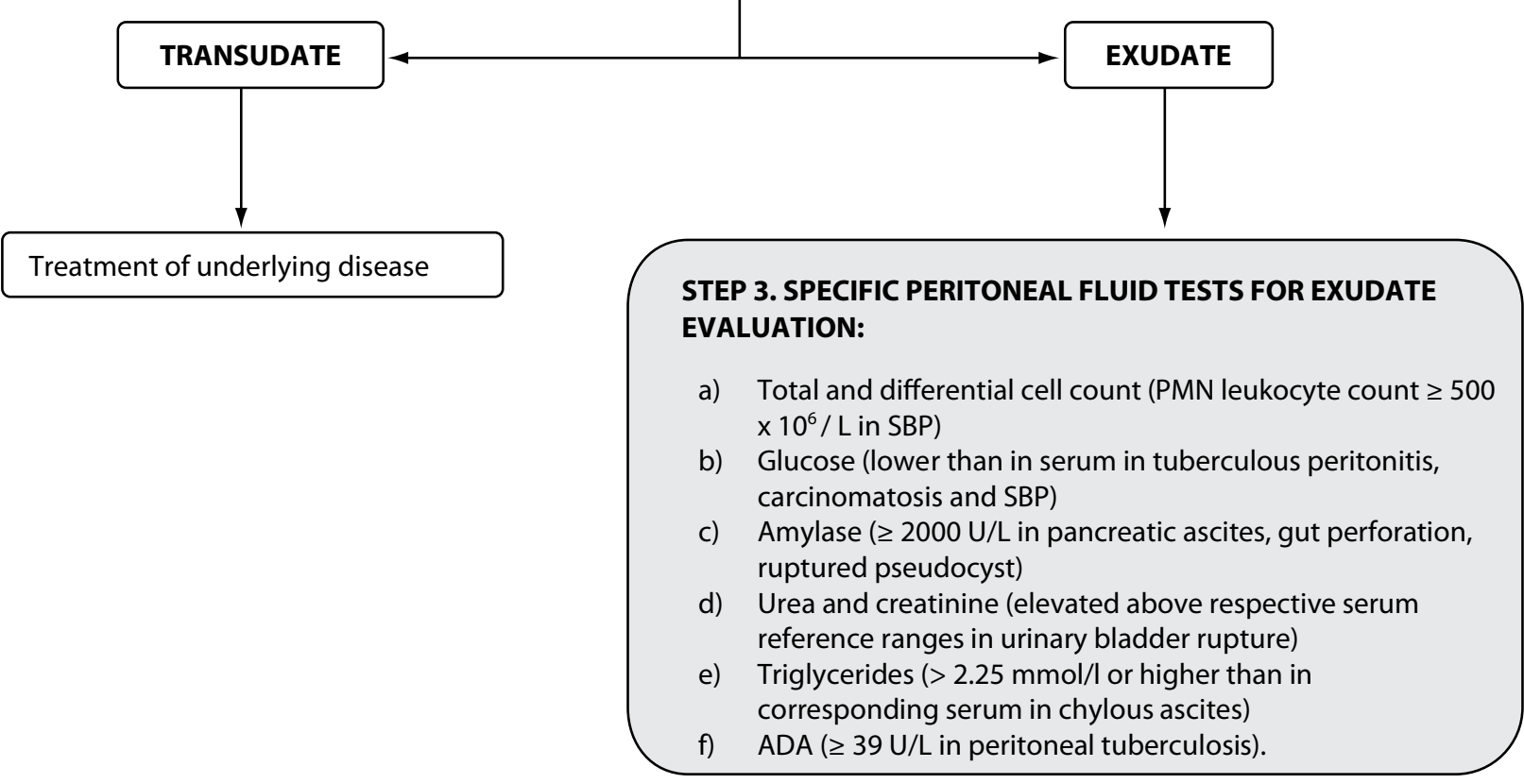

Figure 2. Biochemical analysis of peritoneal effusions.

LD - lactate dehydrogenase; SAAG - serum ascites albumin gradient; SBP - spontaneous bacterial peritonitis; ADA - adenosine deaminase.

It is important to note some methodological issues regarding albumin determination. In patients with cirrhosis, serum albumin concentrations below 11 $\mathrm{g} / \mathrm{L}$ can be expected. In this case, depending on method assay range, incorrect results of SAAG calculation due to assay inaccuracy in the low range could occur, or the SAAG cannot be calculated at all. Chylous ascites can have falsely elevated albumin concentrations due to lipid fraction interference. Furthermore, since globulins contribute to the colloid osmotic pressure, but are inversely correlated to the SAAG, the presence of hyperglobulinemia ( $>50 \mathrm{~g} / \mathrm{L}$ ) can have a pronounced impact on SAAG, falsely decreasing its values $(6,45,56)$. It is 
still unclear if the time interval between serum and ascites sampling is of importance for SAAG calculation (57).

\section{Specific analyses for ascites evaluation}

After differentiation of ascites into two broad categories, specific biochemical analyses can be useful for further evaluation of ascites etiology (Figure 2).

All ascitic fluid samples should be screened for the development of spontaneous bacterial peritonitis (SBP). PMN leukocyte count in ascitic fluid $\geq 250 \mathrm{x}$ $10^{6} / \mathrm{L}$ is the gold standard criterion for SBP diagnosis. Although not specific, it is a highly sensitive indicator of SBP. Ascitic PMN count of $\geq 500 \times 10^{6} /$ $L$ is considered specific for the diagnosis of SBP $(47,55,58,59)$. Because of poor prognosis, antibiotic treatment must be instituted immediately in all patients with suspected SBP, without waiting for microbiology test results (59). In order to reduce time for diagnosis, the usefulness of leukocyte esterase strip testing for diagnosing SBP in cirrhotic patients with ascites was investigated. Very high sensitivity and specificity of urine strip tests were reported compared against the gold standard. Additionally, it was suggested that the rapidity, low cost and wide availability of urine test strips could improve the management of patients with SBP, especially in cases of inflammatory cell clumping in ascitic fluid specimens (60-62). The determination of glucose in ascitic fluid is of little relevance in elucidating the etiology of ascites. Glucose concentrations found in ascitic fluid reflect those found in serum. However, low glucose has been reported in tuberculous peritonitis, carcinomatosis and SBP due to leukocyte or bacterial consumption. Decreased ascites protein concentrations are associ-

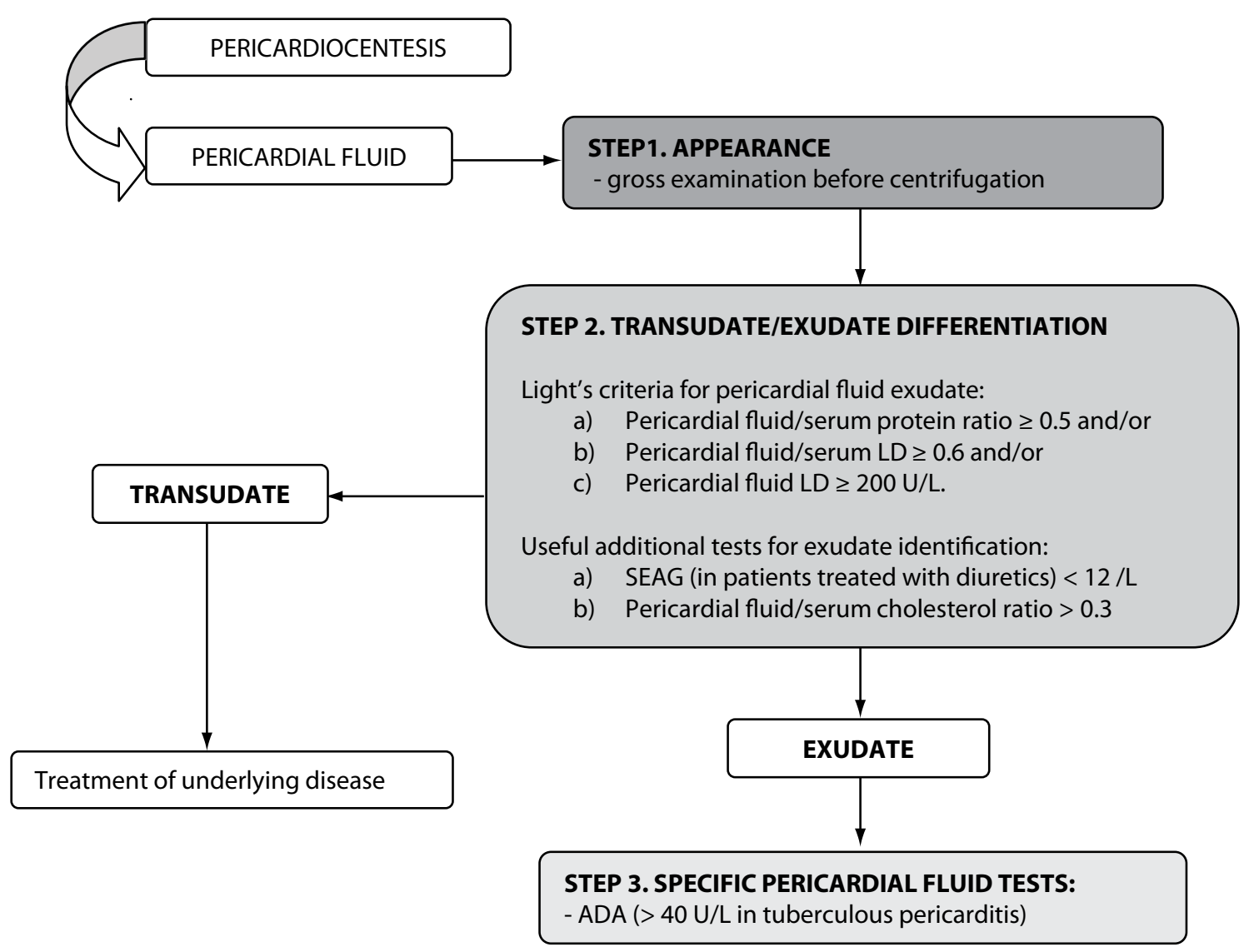

Figure 3. Biochemical analysis of pericardial effusions.

LD - lactate dehydrogenase; SEAG - serum effusion albumin gradient; ADA - adenosine deaminase. 
ated with high risk for developing SBP. AMY activity in ascitic fluid $\geq 2000 \mathrm{U} / \mathrm{L}$ is useful in identifying pancreatic ascites. Elevated ascitic AMY activity is also found in gut perforation with leakage into the peritoneum, ruptured pseudocysts and mesenteric thrombosis $(6,45)$. The diagnostic utility of several tumor markers has been evaluated in diagnosing malignant ascites, especially in situations of inconclusive cytological findings. In general, they are considered of little clinical value compared to corresponding analyses in serum (63). Determinations of urea and creatinine concentrations in ascitic fluid can be useful to differentiate ascites from urine (45). Elevated concentrations of ascitic fluid urea and creatinine compared to simultaneously drawn serum, associated with elevated serum urea but normal serum creatinine, are indicative of the presence of urine (64). Chylous ascites is a rare but serious complication of abdominal surgery, abdominal malignancies, inflammatory diseases, abdominal infections or trauma. Chylous ascites can be differentiated from pseudochylous effusions by its high triglyceride concentration (higher than $2.25 \mathrm{mmol} / \mathrm{L}$ or higher than in corresponding serum) $(45,65,66)$. However, since lymphatic fluid triglyceride concentration is associated with the patient's nutritional status, the determination of triglyceride levels in serum and ascites simultaneously is necessary. Alternatively, ascites triglyceride concentration higher than $1.2 \mathrm{mmol} / \mathrm{L}$ are considered suggestive of chylous ascites (65). A systematic review, investigating the usefulness of ADA in ascitic fluid as a diagnostic tool in peritoneal tuberculosis, included 254 patients and revealed an optimal ADA cut off point at $\geq 39 \mathrm{U} / \mathrm{L}$. An excellent diagnostic efficiency for the diagnosis of peritoneal tuberculosis was found with a sensitivity of $100 \%$ and specificity of $97 \%$ (67). In specific situations, the determination of other parameters in ascitic fluid may be clinically relevant: total bilirubin in cases of biliary leak, ALP in cases of intestinal obstruction or perforation, ammonia in cases of ruptured appendix, lactic acid in bacterial peritonitis, GGT in patients with alcoholic cirrhosis (6).

\section{Pericardial effusions}

Pericardial effusions are characterized by accumulation of fluid in the pericardial space due to injury of the pericardium or pericarditis (6). Transudative pericardial effusions are usually associated with heart failure, hypoalbuminemia, post-radiation therapy and renal insufficiency, while exudative effusions result secondary to pericardial inflammatory, infectious, malignant or auto-immune processes $(6,68)$. Echocardiography is used to diagnose the presence of pericardial effusions, but cannot be used to clearly determine their etiology. Pericardiocentesis, the removal of pericardial fluid, is used both for diagnostic and therapeutic purposes (6).

\section{Appearance of pericardial fluid}

Pericardial fluid is clear and pale yellow. Turbid fluid is indicative of infection or malignancy. Bloody fluid suggests malignant or tuberculous etiology. A milky appearance results from the presence of chylopericardium (6).

\section{Differentiation of exudative from transudative pericardial effusions}

Contrary to the well-established biochemical evaluation of pleural effusions, data concerning the diagnostic usefulness of biochemical tests for the evaluation of pericardial fluid are scarce. Meyers et al. evaluated the ability of various biochemical tests to correctly classify effusions as transudates or exudates in a retrospective study. The authors showed that exudative and transudative pericardial effusions can be differentiated using fluid total protein concentrations $>30 \mathrm{~g} / \mathrm{L}$, fluid/serum total protein ratio $>0.5$ and fluid $L D>300 \mathrm{U} / \mathrm{L}$. The highest diagnostic accuracy in identifying exudates was obtained using fluid/serum LD ratio $>$ 0.6 (87\%) (69). It must be emphasized that these results must be interpreted with caution because retrospective studies can potentially result in biased results and inaccurate conclusions. In a prospective study, Light's criteria were applied to pericardial effusion differentiation and yielded a diagnostic efficiency of $94 \%$, with a sensitivity and spe- 
cificity in identifying exudates of $98 \%$ and $72 \%$, respectively. Similarly to pleural effusion differentiation, the misclassification of transudative into exudative pericardial fluid was reported when Light's criteria were applied to patients receiving diuretic therapy. The application of the SEAG concept, used in the evaluation of pleural effusions, yielded a sensitivity of $90 \%$ and specificity of $89 \%$ for the identification of pericardial exudates and was superior to Light's criteria in patients on diuretics. Pericardial effusion cholesterol concentrations $\geq 1.2 \mathrm{mmol} / \mathrm{L}$ yielded a diagnostic efficiency of $83 \%$ in identifying pericardial exudates, with a sensitivity of $88 \%$ and specificity of $56 \%$. When fluid/serum cholesterol ratio was calculated, improved diagnostic performances were obtained: a cut-off set at 0.3 yielded a diagnostic efficiency of $88 \%$, sensitivity of $91 \%$ and specificity of $83 \%$ $(6,70)$. However, Ben-Horin et al. investigated the composition of physiological pericardial fluid in a small cohort of patients selected for elective openheart surgery. They found that pericardial fluid concentrations of small molecules (i.e. urea, uric acid, glucose and creatinine) were similar to those found in serum. In contrast, pericardial fluid LD concentration was 2.5-fold higher than serum LD, and total protein concentrations were 0.6 of their serum levels (71). The discriminatory accuracy of pericardial fluid/serum LD ratio, pericardial fluid LD and the pericardial fluid/serum total protein ratio was found to be unsatisfactory (72). Considering these findings, caution is needed when interpreting pericardial fluid LD and total protein according to Light's criteria, because pericardial tran- sudates may have levels of these parameters in the exudative range (70-73).

\section{Evaluation of exudative pericardial effusions}

The measurement of ADA in pericardial effusions has proven to be a rapid and accurate tool in identifying tuberculous pericarditis, especially in high prevalence areas. At a cut-off value set at $40 \mathrm{U} / \mathrm{L}$, the diagnostic usefulness of ADA measurement in tuberculous pericarditis diagnosis yields $88 \%$ sensitivity and $83 \%$ specificity (74). CEA and neuron specific enolase have been investigated to identify malignant pericardial effusions. Although promising, the diagnostic utility of tumor markers is limited by the small number of patients investigated (6).

\section{Preanalytical and analytical considerations}

Since recommendations addressing the preanalytical phase for serous fluid testing are unavailable, serous fluid collection, handling and processing should be performed following the guidelines for serum or plasma specimens (64). After collection, serous fluid samples should be transferred into appropriate containers (Table 3 ) and immediately transported to the laboratory $(75,76)$. Serum samples for the calculation of ratios and gradients should be collected within $\mathbf{3 0}$ minutes from serous fluid sampling (3).

In recognition of the difficulties faced by clinical laboratories in serous fluid analysis the Clinical and Laboratory Standards Institute (CLSI) developed

TABLE 3. Containers used for serous fluid biochemical analysis.

\begin{tabular}{ccc}
\hline Analysis & Container & Recommendation \\
\hline pH analysis & heparinized syringe & $\begin{array}{c}\text { sampling done in anaerobic conditions; analyze promptly using a } \\
\text { blood gas analyzer }\end{array}$ \\
\hline $\begin{array}{c}\text { Cell count, } \\
\text { differential cell count }\end{array}$ & EDTA-anticoagulated tube & after collection, mix well \\
\hline Biochemical analyses & $\begin{array}{c}\text { non-additive or } \\
\text { heparin-anticoagulated } \\
\text { containers/tubes }\end{array}$ & $\begin{array}{c}\text { allow complete clotting of samples collected in non-additive } \\
\text { containers/tubes at room temperature; bloody and turbid serous } \\
\text { fluids may be unsuitable for analysis }\end{array}$ \\
\hline Glucose, lactate & tubes with glycolitic inhibitors & lactate: specimen chilling during transportation to the laboratory \\
\hline
\end{tabular}

EDTA - ethylenediaminetetraacetic acid. 
the document C49-A: Analysis of body fluids in clinical chemistry. A brief summary of the acceptable practice without the need for extensive method verification procedures is given in Table 4 $(10,64,75)$.

\section{Conclusions}

When analyzing serous fluids, an approach addressing directly a specific clinical question, guided by the collaboration of specialists in laboratory medicine and clinicians, seems to be more appropriate and ultimately cost-effective than ordering a set of all available tests. Accordingly, diagnostic algorithms should be adopted to establish the biochemical analysis of serous fluids as an efficient tool helping the management of patients with serous effusions.

\section{Potential conflict of interest}

None declared

TABLE 4. Recommendations for acceptable practice in serous fluids analysis $(10,64,75)$.

\section{Recommendation}

- The lack of manufacturers' claims for alternate samples obligates clinical laboratories to verify the performance of commercial assays for their possible use in serous fluid analysis.

- The preconditions for using a commercial assay for analysis in an alternate body fluid include that the measurement system in the routine specimen type has acceptable test characteristics, has calibrators and controls, is traceable to a reference method and has available external proficiency testing.

- Matrix effects, resulting from variations in serous fluid constituents' concentrations, can alter fluid surface tension, viscosity and miscibility in a reaction mixture and potentially influence the measurements in assays intended for use in standard fluid analysis (inaccurate pipetting, inadequate mixing). This matrix effects can potentially cause erroneous results and should be given full consideration when analyzing serous fluids.

- Lack of reference ranges for serous fluid analysis should be compensated for by interpreting the results in conjunction with simultaneously collected serum specimens.

- The test report should include the measured value, type of fluid tested and a statement that accuracy might be affected by sample type, and that the obtained results should be interpreted in the clinical context.

\section{References}

1. Porcel JM, Light RW. Diagnostic approach to pleural effusion in adults. Am Fam Physician 2006;73:1211-20.

2. Light RW. Pleural effusions. Med Clin N Am 2011;95:105570. http://dx.doi.org/10.1016/j.mcna.2011.08.005.

3. Balfe A, Barry S, Blake O, Cannon D, Healy M, Kilbane M et al. Association of Clinical Biochemists in Ireland. The biochemistry of body fluids [Electronic version]. Available at. http://www.acbi.ie/. Accessed July 23rd 2013.

4. Hassan T, Al-Alawi M, Chotirmall SH, McElvaney NG. Pleural fluid analysis: standstill or a work in progress? Pulm Med Hindawi 2012 (article ID 716235).

5. Light RW. Pleural effusion. N Engl J Med 2002;346:1971-7. http://dx.doi.org/10.1056/NEJMcp010731.
6. Burgess LJ. Biochemical analysis of pleural, peritoneal and pericardial effusions. Clin Chim Acta 2004;343:61-84. http://dx.doi.org/10.1016/j.cccn.2004.02.002.

7. McGrath EE, Anderson PB. Diagnosis of pleural effusion: a systematic approach. Am J Crit Care 2011;20:119-28. http://dx.doi.org/10.4037/ajcc2011685.

8. Segura RM. Useful clinical biological markers in diagnosis of pleural effusions in children. Paed Respir Rev 2004;5(Suppl A):S205-12. http://dx.doi.org/10.1016/S15260542(04)90039-5.

9. Roth BJ, O'Meara TF, Hal Cragun W. The serum-effusion albumin gradient in the evaluation of pleural effusions. Chest 1990;98:546-9. http://dx.doi.org/10.1378/chest.98.3.546. 
10. Tarn AC, Lapworth R. Biochemical analysis of pleural fluid: what should we measure? Ann Clin Biochem 2001;38:31122. $h$ ttp://dx.doi.org/10.1258/0004563011900812.

11. Romero-Candeira S, Hernandez L, Romero-Brufao S, Orts $D$, Fernandez C, Martin C. Is it meaningful to use biochemical parameters to discriminate between transudative and exudative pleural effusions? Chest 2002;122:1524-9. http:// dx.doi.org/10.1378/chest.122.5.1524.

12. Ferraz Maranhao BH, da Silva Junior CT, da Silva Chibante AM, Perez Cardoso G. Determination of total proteins and lactate dehydrogenase for the diagnosis of pleural transudates and exudates: redefining the classical criterion with a new statistical approach. J Bras Pneumol 2010;36:468-74.

13. Hamm H, Brohan U, Bohmer R, Missmahl HP. Cholesterol in pleural effusions. Chest 1987;92:296-302. http://dx.doi. org/10.1378/chest.92.2.296.

14. Romero S, Candela A, Martin C, Hernandez L, Trigo C, Gil J. Evaluation of different criteria for the separation of pleural transudates from exudates. Chest 1993;104:399-404. http://dx.doi.org/10.1378/chest.104.2.399.

15. Burgess LJ, Maritz FJ, Frans Taljaard JJ. Comparative analysis of the biochemical parameters used to distinguish between pleural transudates and exudates. Chest 1995;107:1604-9. http://dx.doi.org/10.1378/chest.107.6.1604.

16. Porcel JM, Vives $M$, Vicente De Vera MC, Cao G, Rubio $M$, Rivas C. Useful tests on pleural fluid that distinguish transudates from exudates. Ann Clin Biochem 2001;38:671-5. http://dx.doi.org/10.1258/0004563011901082.

17. Costa M, Quiroga T, Cruz E. Measurement of pleural fluid cholesterol and lactate dehydrogenase. A simple and accurate set of indicators for separating exudates from transudates. Chest 1995;108:1260-3. http://dx.doi.org/10.1378/ chest.108.5.1260.

18. Digensoy O, Celik N, Kul S, Gogebakan B, Bayram H, Light $R W$. Ischemia modified albumin in the differential diagnosis of pleural effusions. Respiratory Medicine 2011;105:1712-7. http://dx.doi.org/10.1016/j.rmed.2011.07.015.

19. Metintas M, Alatas O, Alatas F, Colak O, Ozdemir N, Erginel S. Comparative analysis of biochemical parameters for differentiation of exudates from transudates. Light's criteria, cholesterol, bilirubin, albumin gradient, alkaline phosphatase, creatin kinase, and uric acid. Clin Chim Acta 1997;264:14962. $h$ ttp://dx.doi.org/10.1016/S0009-8981(97)00091-0.

20. Porcel HM, Vives $M$, Cao G, Esquerda A, Rubio M, Rivas C. Measurement of pro-brain natriuretic peptide in pleural fluid for the diagnosis of pleural effusions due to heart failure. Am J Med 2004;116:417-20. http://dx.doi.org/10.1016/j. amjmed.2003.11.008.

21. Romero-Candeira S, Fernandez C, Martin C, Sanchez-Paya $J$, Hernandez $L$. Influence of diuretics on the concentration of proteins and other components of pleural transudates in patients with heart failure. Am J Med 2001;110:681-6. http://dx.doi.org/10.1016/S0002-9343(01)00726-4.

22. McGrath EE, Warriner D, Anderson PB. The use of non-routine pleural fluid analysis in the diagnosis of pleural effusion. Resp Med 2010;104:1092-100. http://dx.doi.org/10.1016/j. rmed.2010.03.008.
23. Porcel JM, Martinez-Alonso M, Cao G, Bielsa S, Sopena A, Esquerda A. Biomarkers of heart failure in pleural fluid. Chest 2009;136:671-7. http://dx.doi.org/10.1378/chest.090270.

24. Kolditz $M$, Halank $M$, Schienmanck CS, Schmeisser A, Hoffken $G$. High diagnostic accuracy of NT-proBNP for cardiac origin of pleural effusions. Eur Respir J 2006;28:144-50. http://dx.doi.org/10.1183/09031936.06.00113205.

25. Han CH, Choi JE, Ching JH. Clinical utility of pleural fluid NTpro brain natriuretic peptide (NT-proBNP) in patients with pleural effusions. Inter Med 2008;47:1669-74. http://dx.doi. org/10.2169/internalmedicine.47.1276.

26. Heffner JE, Brown LK, Barbieri CA. Diagnostic value of tests that discriminate between exudative and transudative pleural effusions. Chest 1997;111:970-80. http://dx.doi. org/10.1378/chest.111.4.970.

27. Heffner JE, Sahn SA, Brown LK. Multilevel likelihood ratios for identifying exudative pleural effusions. Chest 2002;121:1916 20. http://dx.doi.org/10.1378/chest.121.6.1916.

28. Heffner JE, Highland K, Brown LK. A meta-analysis derivation of continuous likelihood ratios for diagnosing pleural fluid exudates. Am J Respir Crit Care Med 2003;167:1591-9. http://dx.doi.org/10.1164/rccm.200301-048PP.

29. Porcel JM, Pena JM, Vicente de Vera C, Esquerda A, Vives $M$, LightRW. Bayesian analysis using continuouslikelihoodratios for identifying pleural exudates. Resp Med 2006;100:1960-5. http://dx.doi.org/10.1016/j.rmed.2006.02.025.

30. Sahn SA. Getting the most from pleural fluid analysis. Respirology 2012;17:270-7. http://dx.doi.org/10.1111/j.14401843.2011.02100.x.

31. Maskell NA, Butland RJA. BTS guidelines for the investigation of a unilateral pleural effusion in adults. Thorax 2003;58(Suppl II):ii8-ii17. http://dx.doi.org/10.1136/thx.58. suppl_2.ii8.

32. Skouras V, Kalomenidis I. Chylothorax: diagnostic approach. Curr Opin Pulm Med 2010;16:387-93. http://dx.doi. org/10.1097/MCP.0b013e328338dde2.

33. Krenke $R$, Korczynski P. Use of pleural fluid levels of adenosine deaminase and interferon gamma in the diagnosis of tuberculous pleuritis. Curr Opin Pulm Med 2010;16:367-75. http://dx.doi.org/10.1097/MCP.0b013e32833a7154.

34. Hiraki A, Aoe K, Eda R, Maeda T, Murakami T, Sugi K, Takeya$\mathrm{ma} \mathrm{H}$. Comparison of six biological markers for the diagnosis of tuberculous pleuritis. Chest 2004;125:987-9. http:// dx.doi.org/10.1378/chest.125.3.987.

35. Jiang J, Shi HZ, Liang QL, Qin SM, Qin XJ. Diagnostic value of interferon- $\gamma$ in tuberculous pleurisy. Chest 2007;131:113341.http://dx.doi.org/10.1378/chest.06-2273.

36. Trajman $A$, Pai $M$, Dheda $K$, van Zyl Smit $R$, Zwerling $A A$, Joshi $R$, et al. Novel tests for diagnosing tuberculous pleural effusion: what works and what does not? Eur Respir J 2008;31:1098-106. http://dx.doi.org/10.1183/09031936. 00147507.

37. McGrath EE, Warriner $D$, Anderson PB. Pleural fluid characteristics of tuberculous pleural effusions. Heart Lung 2010;39:540-3. http://dx.doi.org/10.1016/j. hrtlng.2009.12.004. 
38. Liang QL, Shi HZ, Wang K, Qin SM, Qin XJ. Diagnostic accuracy of adenosine deaminase in tuberculous pleurisy: a meta-analysis. Respir Med 2008;102:744-54. http://dx.doi. org/10.1016/j.rmed.2007.12.007.

39. Ferrer J, Villarino MA, Encabo G, Felip E, Bermejo B, Vila S, Orriols R. Diagnostic utility of CYFRA 21-1, carcinoembryonic antigen, CA 125, neuron specific enolase, and squamous cell antigen level determinations in the serum and pleural fluid of patients with pleural effusions. Cancer 1999;86:1488-95. http://dx.doi.org/10.1002/(SICI)10970142(19991015)86:8<1488::AID-CNCR15>3.0.CO;2-Y.

40. Porcel JM, Vives $M$, Esquerda A, Salud A, Perez B, Rodriguez-Panadero $F$. Use of a panel of tumor markers (carcinoembryonic antigen, cancer antigen 125 , carbohydrate antigen 15-3, and cytokeratin 19 fragments) in pleural fluid for the differential diagnosis of benign and malignant effusion. Chest 2004;126:1757-63. http://dx.doi.org/10.1378/ chest.126.6.1757.

41. Villena V, Perez V, Pozo F, Lopez-Encuentra A, Echave-Sustaeta J, Arenas J, Escribano PM. Amylase levels in pleural effusions: a consecutive unselected series of 841 patients. Chest 2002;121:470-4. http://dx.doi.org/10.1378/chest.121.2.470.

42. Branca P, Rodriguez RM, Rogers JT, Ayo DS, Moyers JP, Light $R W$. Routine measurement of pleural fluid amylase is not indicated. Arch Intern Med 2001;161:228-32. http://dx.doi. org/10.1001/archinte.161.2.228.

43. Light RW. The undiagnosed pleural effusion. Clin Chest Med 2006;27:309-19. http://dx.doi.org/10.1016/j.ccm.2005.12.002.

44. Kiropoulos TS, Kostikas K, Oikonomidi S, Tsilioni I, Nikoulis D, Germenis A, Gourgoulianis KI. Acute phase markers for the differentiation of infectious and malignant pleural effusions. Respir Med 2007;101:910-18. http://dx.doi. org/10.1016/j.rmed.2006.09.019.

45. Tarn AC, Lapworth R. Biochemical analysis of ascitic (peritoneal) fluid: what should we measure? Ann Clin Biochem 2010;47:397-407. http://dx.doi.org/10.1258/acb.2010. 010048.

46. Sood R. Ascites: diagnosis and management. Journal of Indian Academy of Clinical Medicine 2000;5:80-9.

47. Runyon BA. Management of adult patients with ascites due to cirrhosis. Hepatology 2004;39:841-56. http://dx.doi. org/10.1002/hep.20066.

48. Saravanan $R$, Cramp ME. Investigation and treatment of ascites. Clin Med JRCPL 2002;2:310-3. http://dx.doi. org/10.7861/clinmedicine.2-4-310.

49. Runyon BA, Montano AA, Akriviadis EA, Antillon MR, Irving $M A, M c H u t c h i n s o n$ JG. The serum-ascites albumin gradient is superior to the exudate-transudate concept in the differential diagnosis of ascites. Ann Int Med 1992;117:21520. $h$ ttp://dx.doi.org/10.7326/0003-4819-117-3-215.

50. Vyakaranam S, Nori S, Sastry G, Vyakaranam SB, Bhongir AV. Serum-ascites albumin and cholesterol gardients in differential diagnosis of ascites. NJIRM 2011;2:22-8.

51. Alexandrakis MG, Moschandrea JA, Koulocheri SA, Kouroumalis E, Eliopoulos GD. Discrimination between malignant and nonmalignant ascites using serum and ascitic fluid proteins in a multivariate model. Dig Dis Sci 2000;45:500-8. http://dx.doi.org/10.1023/A:1005437005811.
52. Pare P, Talbot J, Hoefs JC. Serum-ascites albumin concentration gradient: a physiologic approach to the differential diagnosis of ascites. Gastroenterology 1983;85:240-4.

53. Al-Knawy BA. Etiology of ascites and the diagnostic value of serum-ascites albumin gradient in non-alcoholic liver disease. Ann Saudi Med 1997;17:26-8.

54. Beg M, Hussain S, Ahmad N, Akhtar N. Serum/ascites albumin gradient in differential diagnosis of ascites. JIACM 2001;2:51-4.

55. Moore KP, Aithal GP. Guidelines on the management of ascites in cirrhosis. Gut 2006;55(Suppl VI):vi1-vi12. http:// dx.doi.org/10.1136/gut.2006.099580.

56. Hoefs JC. Globulin correction of the albumin gradient: correlation with measured serum to ascites colloid osmotic pressure gradients. Hepatology 1992;16:396-403. http:// dx.doi.org/10.1002/hep.1840160218.

57. Jenkinson F, Murphy MJ. Biochemical analysis of pleural and ascitic fluid: effect of sample timing on interpretation of results. Ann Clin Biochem 2007;44:471-3. http://dx.doi. org/10.1258/000456307781645978.

58. Albillos A, Cuervas-Mons V, Millan I, Canton T, Montes J, Barrios $C$, et al. Ascitic fluid polymorphonuclear cell count and serum to ascites albumin gradient in the diagnosis of bacterial peritonitis. Gastroenterology 1990;98:134-40.

59. Rimola A, Garcia-Tsao G, Navasa M, Piddock LVJ, Planas $R$, Bernard $B$ et al. Diagnosis, treatment and prophylaxis of spontaneous bacterial peritonitis: a consensus document. $J$ Hepatol 2000;32:142-53. http://dx.doi.org/10.1016/S01688278(00)80201-9.

60. Kim DY, Kim JH, Chon CY, Han K-H, Ahn SH, Kim JK, et al. Usefulness of urine strip test in the rapid diagnosis of spontaneous bacterial peritonitis. Liver International 2005;25:1197201. http://dx.doi.org/10.1111/j.1478-3231.2005.01176.x.

61. Braga LLBC, Souza MHLP, Barbosa AMC, Furtado FM, Campelo PAM, Filho AHA. Diagnosis of spontaneous bacterial peritonitis in cirrhotic patients in north eastern Brazil by use of rapid urine-screening test. Sao Paulo Med J 2006;124:141-4. http://dx.doi.org/10.1590/S151631802006000300006

62. Castellote J, Lopez C, Gornals J, Tremosa G, Rodriguez Farina E, Baliellas C, et al. Rapid diagnosis of spontaneous bacterial peritonitis by use of reagent strips. Hepatology 2003;37:89396. $h$ ttp://dx.doi.org/10.1053/jhep.2003.50120.

63. Tuzun Y, Elik YC, Bayan K, Yilmaz S, Dursun M, Canoruc F. Correlation of tumor markers in ascitic fluid and serum: are measurements of ascitic tumor markers a futile attempt? J Int Med Res 2009;37:79-86. http://dx.doi. org/10.1177/147323000903700109.

64. Karcher DS, McPherson RA. Cerebrospinal, synovial, serous body fluids and alternative specimens. In: McPherson RA, Pincus MR, eds. Henry's clinical diagnosis and management by laboratory methods [Electronic version]. Philadelphia: Elsevier/Saunders; 2011. p.480-510. Available at: http://www. mdconsult.com/books. Accessed November 11th 2013.

65. Van der Gaag NA, Verhaar AC, Haverkort EB, Busch ORC, van Gulik TM, Gouma DJ. Chylous ascites after pancreaticoduodenectomy: introduction of grading system. J Am Coll Surg 2008;207:751-7. http://dx.doi.org/10.1016/j. jamcollsurg.2008.07.007. 
66. Tulunay $G$, Ureyen I, Turan T, Karalok A, Kavak D, Ozgul N, et al. Chylous ascites: analysis of 24 patients. Gynecol Oncol 2012;127:191-7. http://dx.doi.org/10.1016/j. ygyno.2012.06.023.

67. Riquelme A, Calvo M, Salech F, Valderrama S, Pattillo A, AreIlano $M$, et al. Value of adenosine deaminase (ADA) in ascitic fluid for the diagnosis of tuberculous peritonitis. A metaanalysis. J Clin Gastroenterol 2006;40:705-10. http://dx.doi. org/10.1097/00004836-200609000-00009.

68. Dennebaum R. Pericardial effusion. In: Thomas L, ed. Clinical laboratory diagnostics: use and assessment of clinical laboratory results. Frankfurt/Mein: TH Books;1998. p.134856.

69. Meyers DG, Meyers RE, Prendergast TW. The usefulness of diagnostic tests on pericardial fluid. Chest 1997;111:121321. http://dx.doi.org/10.1378/chest.111.5.1213.

70. Burgess LJ, Reuter H, Frans Taljaard JJ, Doubell AF. Role of biochemical tests in the diagnosis of large pericardial effusions. Chest 2002;121:495-9. http://dx.doi.org/10.1378/ chest.121.2.495.

71. Ben-Horin S, Shinfeld A, Kachel E, Chetrit A, Livneh A. The composition of normal pericardial fluid and its implications for diagnosing pericardial effusions. Am J Med 2005; 118:63640. http://dx.doi.org/10.1016/j.amjmed.2005.01.066.
72. Ben-Horin S, Bank I, Shinfeld A, Kachel E, Guetta V, Livneh A. Diagnostic value of the biochemical composition of pericardial effusions in patients undergoing pericardiocentesis. Am J Cardiol 2007;99:1294-7. http://dx.doi.org/10.1016/j. amjcard.2006.12.048.

73. Cale-Subia LN, de Luna AM. Applicability of Light's criteria in the biochemical analysis of pericardial fluid. Phil Heart Center J 2012;16:50-4.

74. Tuon FF, Nobrega Litvoc M, Ferreira Lopes MIB. Adenosine deaminase and tuberculous pericarditis - a systema tic review with meta-analysis. Acta Tropica 2006;99:67-74. http://dx.doi.org/10.1016/j.actatropica.2006.07.004.

75. Calgary Laboratory Services. Body fluid collection guidelines. Available at: http://www.calgarylabservices.com/education-research/medical-professionals-education. Accessed November 4th 2013.

76. Cheng $D$, Rodriguez $M$, Rogers J, Wagster $M$, Starnes $D L$, Light RW. Comparison of pleural fluid $\mathrm{pH}$ values obtained using blood gas machine, $\mathrm{pH}$ meter, and $\mathrm{pH}$ indicator strip. Chest 1998;114:1368-72. http://dx.doi.org/10.1378/ chest.114.5.1368. 